\title{
Does the United States Lead Foreign Business Cycles?
}

\author{
Neville Francis, Michael T. Owyang, and Daniel Soques
}

The U.S. financial crisis of 2007-08 had detrimental and lasting effects on the economies of other nations, reinforcing the leading role played by the United States in the global economy. The authors assess this role by determining whether U.S. output growth informs business cycle turning points in the economies of other nations. They find that U.S. economic growth influences both the timing and duration of business cycle phases for Canada, Germany, the United Kingdom, and, to a lesser extent, Mexico. However, they find no relationship between U.S. output growth and the business cycles of France, Italy, and Japan. (JEL E32, F44)

Federal Reserve Bank of St. Louis Review, Second Quarter 2015, 97(2), pp. 133-58.

\footnotetext{
Neville Francis is an associate professor and Daniel Soques is a doctoral student in the department of economics at the University of North Carolina at Chapel Hill. Michael T. Owyang is an assistant vice president and economist at the Federal Reserve Bank of St. Louis. The authors thank Sylvia Kaufmann for helpful conversations. Diana A. Cooke, Hannah G. Shell, and E. Katarina Vermann provided research assistance.

○ 2015, The Federal Reserve Bank of St. Louis. The views expressed in this article are those of the author(s) and do not necessarily reflect the views of the Federal Reserve System, the Board of Governors, or the regional Federal Reserve Banks. Articles may be reprinted, reproduced, published, distributed, displayed, and transmitted in their entirety if copyright notice, author name(s), and full citation are included. Abstracts, synopses, and other derivative works may be made only with prior written permission of the Federal Reserve Bank of St. Louis.
} 


\section{Francis, Owyang, Soques}

countries. Canada, Latin American, and Caribbean countries are the most strongly influenced within their sample. Lastly, they use the more dynamic approach of structural vector autoregressions to allow for both foreign and domestic effects. They find that U.S. growth has significant effects on growth in Latin America, the Asian newly industrialized economies (Hong Kong, Korea, Singapore, and Taiwan), and some of the Association of Southeast Asian Nations (Indonesia, Malaysia, the Philippines, and Thailand). Antonakakis (2012) uses a dynamic measure of correlation to examine the synchronization of G-7 business cycles across a long time series (1870 to 2011). He finds U.S. recessions have positive effects on business cycle comovements after the 1971 breakdown of the Bretton Woods system, with an increased level of synchronization during the Great Recession.

The goal of this article is to assess the influence of U.S. output growth on the business cycles of other nations. In particular, we ask whether U.S. economic growth signals economic turning points in other countries. In our model, we cannot determine which structural innovations (shocks) drive spillovers from the United States onto the economies of other countries or whether the proximate shock leading to the turning point is global in nature. Rather, we are merely interested in the comovement between U.S. output and economic downturns in other countries. However, we do analyze the timing and duration of the effects of the U.S. economy on the business cycles of other countries. Accordingly, we could appeal to other studies regarding which driving forces occurred during a given time period. ${ }^{1}$

Despite the inability of our model to offer a complete characterization of these shocks, our study should be of relevant interest to policymakers and others interested in the dependence of foreign business cycles on the U.S. economy. Our results imply that the trajectory of U.S. output growth informs both the timing and duration of economic turning points in certain foreign economies. Proper analysis of these cross-country linkages gives policymakers, both in the United States and abroad, a better understanding of the trade-offs faced when conducting independent and coordinated actions.

Since our focus is on economic turning points, we use the regime-switching model of Hamilton (1989) with time-varying transition probabilities (TVTP) as outlined by Goldfeld and Quandt (1973), Diebold, Lee, and Weinbach (1994), and Filardo (1994). This framework allows us to identify not only the economic turning points but also the extent to which U.S. output growth influences the evolution of the underlying state-recession or expansion-of a nation's economy. We consider regime-switching models with both two states ("recession" and "expansion") and three states ("recession," "low-growth expansion," and "high-growth expansion”).

Our panel of countries includes Canada, France, Germany, Italy, Japan, Mexico, and the United Kingdom and covers the period 1960:Q2-2013:Q4. We find that U.S. output growth informs the timing and duration of recessions for Canada, Germany, the United Kingdom, and, to a lesser extent, Mexico. We find no relationship between U.S. output growth and business cycle turning points for the remaining countries (France, Italy, and Japan).

The article proceeds as follows: The next section details the regime-switching model and is followed by a section that describes the data and outlines the estimation methodology. Our results are presented in the next section, followed by our conclusions. 


\section{MODEL}

Burns and Mitchell (1946) characterize the business cycle as distinct phases of expansion and recession. As defined by the National Bureau of Economic Research (NBER) Business Cycle Dating Committee, a recession is a widespread decline in economic activity typically lasting from a few months to over a year. On the other hand, expansions are characterized by positive growth in economic activity and, typically, longer durations.

Models of a country's business cycle are typically estimated using only that country's data. Regime shifts are characterized by sudden and persistent shifts in the growth rate of the economic indicators, usually domestic GDP. In this article, we are interested in the contagion of economic outcomes across countries. To this end, we augment the standard business cycle model to account for possible contagion by a dominant country-in this case, the United States.

The model we adopt is based on the business cycle model of Hamilton (1989), who characterizes the cycle as a two-state process with random regime changes. In his framework, the mean growth rate of a country's output, $y_{t}$, depends on a latent state variable, $s_{t}=\{1,2\}$. The state of the economy at any time is either recession $\left(s_{t}=1\right)$ or expansion $\left(s_{t}=2\right)$. Assuming no autoregressive terms for simplicity, this model is given by

$$
y_{t}=\left\{\begin{array}{l}
\mu_{1}+\varepsilon_{t}, \text { if } s_{t}=1 \text { (recession) } \\
\mu_{2}+\varepsilon_{t}, \text { if } s_{t}=2(\text { expansion) }
\end{array},\right.
$$

where the error variance, $\varepsilon_{t} \sim N\left(0, \sigma^{2}\right)$, is constant across states. Consistent with the NBER's definition of the business cycle, we restrict the average growth rate of output to be positive during expansionary periods $\left(\mu_{2}>0\right)$ and negative during recessionary periods $\left(\mu_{1}>0\right)$.

In principle, we could include any number of states $K$ in the model to better match certain features of business cycles. For example, Kim and Piger (2002), Kim and Murray (2002), and Billio et al. (2013) include three states in their regime-switching model of the business cycle. Additional states can reflect persistent differences in business cycle characteristics such as fast- versus slow-growth expansion regimes or deep versus shallow recessions. The generalized $K$-state model is given by

$$
y_{t}=\left\{\begin{array}{cc}
\mu_{1}+\varepsilon_{t} & \text { if } s_{t}=1, \\
\mu_{2}+\varepsilon_{t} & \text { if } s_{t}=2, \\
\vdots & \vdots \\
\mu_{K}+\varepsilon_{t} & \text { if } s_{t}=K,
\end{array}\right.
$$

with the identifying restriction $\mu_{1}<\mu_{2}<\ldots<\mu_{K}$. We consider both a two-state (recession and expansion) and a three-state (recession, low-growth expansion, and high-growth expansion) model for each country. We normalize the states such that $\mu_{1}<0<\mu_{2}<\mu_{3}$. This normalization provides econometric identification as well as an interpretation for future discussion. 


\section{Francis, Owyang, Soques}

\section{Transition Probabilities}

The NBER's Business Cycle Dating Committee provides ex post historical dates for periods during which the U.S. economy is in expansion or recession. Many other countries do not have "official" business cycle turning points. The model leaves the state of the economy unobserved and, therefore, requires an assumption about the evolution process of the state variable. Ideally, a model of economic business cycles matches two features of the data: (i) Both expansions and recessions are highly persistent and (ii) expansions have longer average durations than recessions.

A standard assumption with regime-switching models is that the state variable follows a first-order Markov process with fixed transition probabilities (FTPs; e.g., as in Hamilton, 1989). The Markov property imposes that the current value of the state variable, $s_{t}$, is a function of its previous value, $s_{t-1}$. In the two-state model, the transition matrix governing the Markov process is represented as

$$
P=\left[\begin{array}{ll}
p_{11} & p_{12} \\
p_{21} & p_{22}
\end{array}\right],
$$

with FTPs

$$
p_{j i}=\operatorname{Pr}\left[s_{t}=j \mid s_{t-1}=i\right] \text {, }
$$

where the columns of $P$ each sum to 1 (i.e., $\Sigma_{j} p_{j i}=1$ for $i=1,2$ ). Thus, if a country was in expansion during the previous period $\left(s_{t-1}=2\right)$, the probability that it remains in expansion this period $\left(s_{t}=2\right)$ is $p_{22}$, and the probability that the economy enters a recession this period $\left(s_{t}=1\right)$ is $p_{12}=1-p_{22}$. Similarly, given that a country was in recession during the previous period $\left(s_{t}=1\right)$, the probability that it remains in recession during this period $\left(s_{t}=1\right)$ is $p_{11}$, and the probability that the economy recovers and enters expansion this period $\left(s_{t}=2\right)$ is $p_{21}=1-p_{11}$.

Persistence is generated in the Markov process when the diagonal elements of the transition matrix are greater than the off-diagonal elements. Previous studies typically find the persistence probability of expansion, $p_{22}$, to be greater than the persistence probability of recession, $p_{11}$, coinciding with the observation that, on average, expansions are longer than recessions. For example, Hamilton (1989) found persistence probabilities for the United States of approximately 0.90 for expansions and 0.75 for recessions, implying expected durations of 10 quarters for expansions and 4 quarters for recessions, similar to those defined by the NBER.

Because we are interested in how U.S. output growth informs economic turning points of other nations, we extend Hamilton's (1989) model to allow a foreign (U.S.) output growth rate to directly affect the evolution of the underlying economic state of other nations. ${ }^{2}$ We assume the Markov process is governed by TVTP, which are functions of exogenous covariates and the previous period's state. In our case, we use the one-period lag of U.S. output growth, $y_{t-1}^{U S}$, as the single covariate, which influences the switching process. The time-varying transition matrix in the two-state model is 


$$
P_{t}=\left[\begin{array}{ll}
p_{11, t} & p_{12, t} \\
p_{21, t} & p_{22, t}
\end{array}\right]
$$

with TVTP

$$
p_{j i, t}=\operatorname{Pr}\left[s_{t}=j \mid s_{t-1}=i, y_{t-1}^{U S}\right]=\frac{\exp \left(\alpha_{j i}+\beta_{j i} y_{t-1}^{U S}\right)}{\sum_{k=1}^{2} \exp \left(\alpha_{k i}+\beta_{k i} y_{t-1}^{U S}\right)} .
$$

Here, $\alpha_{j i}$ is the time-invariant parameter and $\beta_{j i}$ is the coefficient on lagged U.S. output growth, $y_{t-1}^{U S}$. The FTP model is nested under the TVTP framework if the covariate has no effect under each state realization (i.e., $\beta_{j i}=0$ for $i=1,2$ and $j=1,2$ ). Note that the time-invariant parameter $\alpha_{j i}$ and the coefficient $\beta_{j i}$ depend on both the previous state $\left(s_{t-1}=i\right)$ and the potential current state $\left(s_{t}=j\right)$, thereby reflecting the Markov property. Also, this parameterization allows U.S. output growth to have asymmetric effects since we assume the coefficient is state dependent (i.e., $\beta_{j 1} \neq \beta_{j 2}$ for $j=1,2$ and $\beta_{1 i} \neq \beta_{2 i}$ for $i=1,2$ ). To identify the transition parameters, we must normalize one of the state's transition parameters to be zero. For the two-state model, we use state 2: $\alpha_{2 i}=0$ and $\beta_{2 i}=0$ for $i=1,2$.

For the general $K$-state model, the time-varying transition matrix is

$$
P_{t}=\left[\begin{array}{cccc}
p_{11, t} & p_{12, t} & \cdots & p_{1 K, t} \\
p_{21, t} & p_{22, t} & & \\
\vdots & & \ddots & \\
p_{K 1, t} & & & p_{K K, t}
\end{array}\right],
$$

with TVTP

$$
p_{j i, t}=\operatorname{Pr}\left[s_{t}=j \mid s_{t-1}=i, \mathbf{x}_{t}\right]=\frac{\exp \left(\alpha_{j i}+\beta_{j i} y_{t-1}^{U S}\right)}{\sum_{k=1}^{2} \exp \left(\alpha_{k i}+\beta_{k i} y_{t-1}^{U S}\right)},
$$

where we can impose the identification restrictions on state $K: \alpha_{K i}=0$ and $\beta_{K i}=0$ for $i=$ $1,2, \ldots, K$. We collect the unrestricted transition parameters into the $[2 K \times(K-1)]$ matrix $\Gamma=\left[\gamma_{1}, \ldots, \gamma_{K-1}\right]$, where $\gamma_{i}=\left[\alpha_{i 1}, \ldots, \alpha_{i K}, \beta_{i 1}, \ldots \beta_{i K}\right]^{\prime}$ for $i=1, \ldots, K-1$.

\section{Determining the Effects of U.S. Output Growth}

The effect of U.S. output growth on turning points of other countries appears to be summarized by the coefficient $\beta_{j i}$ in the transition equations. However, interpreting these coefficients in the logistic framework of TVTP is less straightforward than in a simple linear regression model. One way to assess the effect of U.S. output growth on the transition dynamics is by analyzing the marginal effect of a change in $y_{t-1}^{U S}$ on each transition probability $p_{j i, t}$ for $j=1, \ldots, K$ 


\section{Francis, Owyang, Soques}

and $i=1, \ldots, K$. We calculate the marginal effect of $y_{t-1}^{U S}$ on $p_{j i, t}$ by taking the partial derivative of equation (2) with respect to $y_{t-1}^{U S}$ :

$$
\frac{\partial p_{j i, t}}{\partial y_{t-1}^{U S}}=p_{j i, t}\left(\beta_{j i}-\bar{\beta}\right)
$$

where $\bar{\beta}=\Sigma_{k} p_{k i, t} \beta_{j i}$ is the probability-weighted mean of the coefficient across states.

In the two-state model, the marginal effect of a change in $y_{t-1}^{U S}$ on the probability of recession $\left(s_{t}=1\right)$ simplifies to

$$
\frac{\partial p_{1 i, t}}{\partial y_{t-1}^{U S}}=\beta_{1 i} p_{1 i, t}\left(1-p_{1 i, t}\right)
$$

which depends on the previous period's state. Determining the sign of this marginal effect is straightforward because it is irrespective of the value of $y_{t-1}^{U S}$ and therefore time invariant. If $\beta_{1 i}<\beta_{2 i}=0$, then the probability of a recession (expansion) next period falls (rises) as lagged U.S. output growth rises. We expect to find this relationship for countries whose economies tend to move with the U.S. economy. Conversely, if $\beta_{1 i}>\beta_{2 i}=0$, then the probability of a recession (expansion) next period rises (falls) as lagged U.S. output growth rises. We expect to find this relationship for countries whose economies move in the opposite direction (decouple) from the U.S. economy. If $\beta_{1 i}=\beta_{2 i}=0$, then the marginal effect is zero and lagged U.S. output growth does not influence the transition probabilities. Therefore, no relationship exists between U.S. output growth and economic turning points for the country under consideration.

Unlike the sign, the magnitude of the marginal effect in the two-state model is time varying because it depends on the value of $y_{t-1}^{U S}$. For example, assume parameter values $\alpha_{11}=-1$ and $\beta_{11}=-1$ in a simple two-state version of our model $(K=2)$. First, consider the case where U.S. output growth is 2 standard deviations above its historical mean $\left(y_{t-1}^{U S}=2\right)$. Then, the marginal effect of further changes in $y_{t-1}^{U S}$ on the persistence probability of recession is -0.05 . However, if U.S. output growth is relatively low at 2 standard deviations below its historical mean $\left(y_{t-1}^{U S}\right.$ $=-2$ ), then the absolute magnitude of this marginal effect quadruples to -0.20 . Thus, the current status of the U.S. economy informs not only the probability of recession in the country of interest but also the current degree of influence of U.S. output growth over this probability.

In the general $K$-state model, both the sign and magnitude of the marginal effects depend on the value of $y_{t-1}^{U S}$. To fully assess the effect of U.S. output growth at different points in time, we calculate the marginal effects over a range of possible values of $y_{t-1}^{U S}$.

\section{DATA AND ESTIMATION}

\section{Data}

We use the seasonally adjusted, annualized quarter-to-quarter growth rate of real GDP as our measure of economic activity growth $\left(y_{t}\right)$ for each country. We use data from the Quarterly National Accounts database provided by the Organisation for Economic Co-operation and Development (OECD). The countries included in our sample are the G-7 counterparts of the 


\section{Table 1}

\section{Sample Statistics}

\begin{tabular}{lcccc} 
Country & Coverage & Mean $(\bar{y})$ & Variance $\left(\sigma_{y}^{2}\right)$ & $\begin{array}{c}\text { Correlation } \\
\text { with U.S. }\left(p_{x, y}\right)\end{array}$ \\
\hline Canada & $1960: Q 2-2013: Q 4$ & 3.19 & 11.89 & 0.52 \\
France & $1970: Q 2-2013: Q 4$ & 2.09 & 5.24 & 0.32 \\
Germany & $1960: Q 2-2013: Q 4$ & 2.44 & 19.56 & 0.27 \\
Italy & $1960: Q 2-2013: Q 4$ & 2.47 & 17.13 & 0.24 \\
Japan & $1960: Q 2-2013: Q 4$ & 3.93 & 28.22 & 0.21 \\
Mexico & $1980: Q 2-2013: Q 4$ & 2.39 & 28.53 & 0.26 \\
United Kingdom & $1960: Q 2-2013: Q 4$ & 2.45 & 15.43 & 0.26 \\
United States & $1960: Q 1-2013: Q 3$ & 3.04 & 11.42 & - \\
\hline
\end{tabular}

United States (Canada, France, Germany, Italy, Japan, and the United Kingdom) and Mexico, given its geographic proximity and economic relationship with the United States. Our time series covers 1960:Q2-2013:Q4 for Canada, Germany, Italy, Japan, and the United Kingdom; 1970:Q2-2013:Q4 for France; and 1980:Q2-2013:Q4 for Mexico. Table 1 provides summary statistics for our sample.

For the transition covariate, $y_{t-1}^{U S}$, we use the one-period lag of U.S. output growth from the OECD's Quarterly National Accounts database for the period 1960:Q1-2013:Q3. To simplify the interpretation of the results, we standardize the time series of U.S. output growth to have zero mean and unit variance. Thus, $y_{t-1}^{U S}=0$ implies the United States is at its historical average growth rate-approximately 3.04 percent-over our sample period. Similarly, $y_{t-1}^{U S}=c$ means the United States is growing at $c$ standard deviations away from its historical average growth rate. For example, $y_{t-1}^{U S}=2$ implies that U.S. output grew at 9.80 percent during the previous period since the standard deviation of U.S. output growth from 1960:Q1 to 2013:Q2 is approximately 3.38 .

Figure 1 plots the time series of real GDP growth for a subset of our sample (Canada, Germany, and Japan). The gray bars indicate U.S. recession dates as defined by the NBER's Business Cycle Dating Committee and are included only for reference. For each country, real GDP growth tends to fall during periods of U.S. recession, implying some connection between U.S. growth and other countries' growth.

\section{Estimation}

We estimate both the two- and three-state models using the Gibbs sampler, a Markov chain Monte Carlo (MCMC) algorithm used in a Bayesian environment. Rather than drawing from the full joint posterior distribution directly, the Gibbs sampler draws each of the four parameter blocks from their individual conditional posterior distribution given the draws for the other blocks. First, we partition the parameters and latent variables into four blocks: (i) the average growth rates, $\mu=\left[\mu_{1}, \ldots, \mu_{K}\right]^{\prime}$; (ii) the error variance, $\sigma^{2}$; (iii) the transition probability param- 


\section{Figure 1}

\section{Real GDP Growth for Canada, Germany, and Japan}
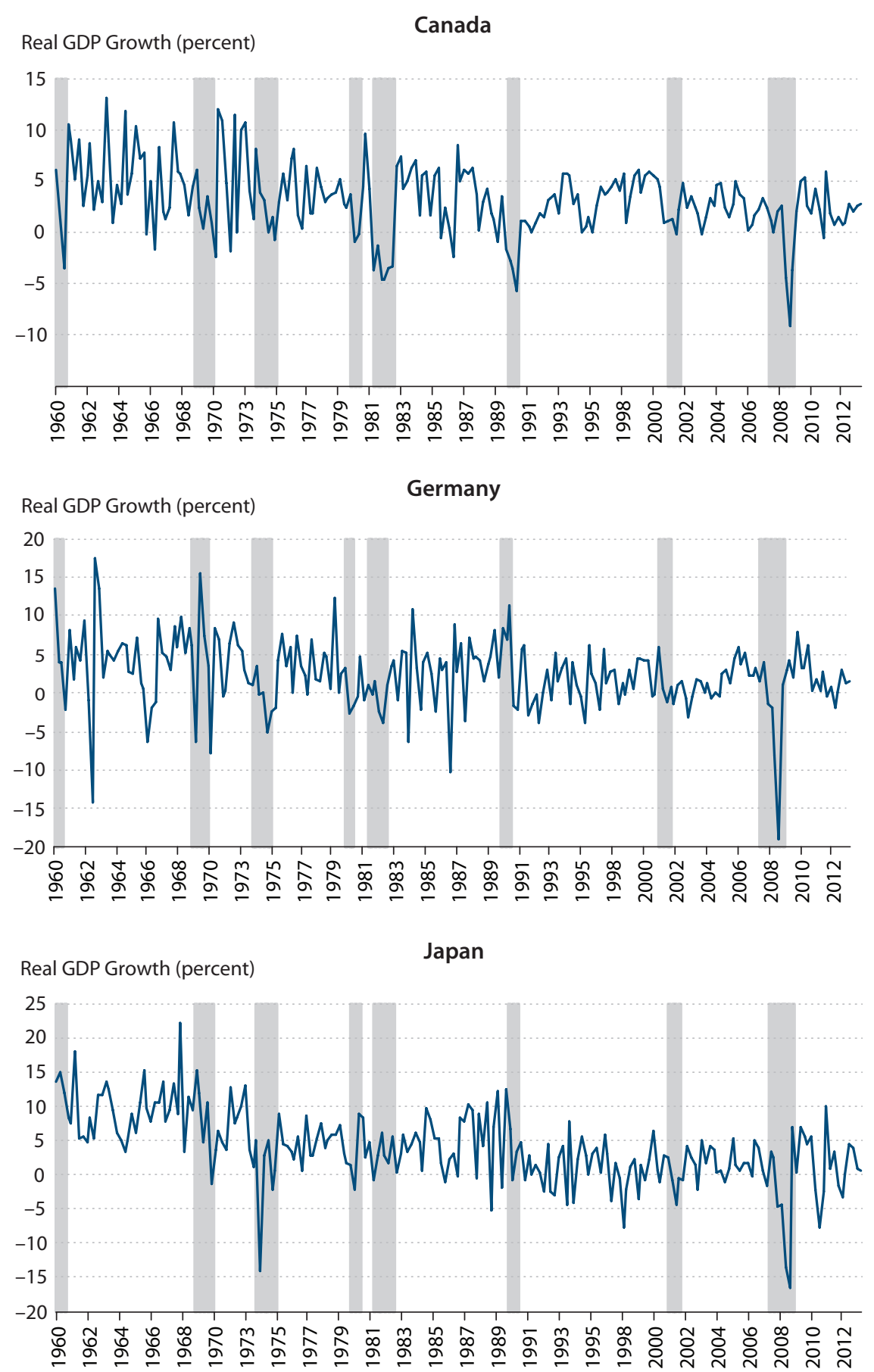

NOTE: The shaded bars indicate U.S. recessions as determined by the National Bureau of Economic Research. SOURCE: Data from the OECD's Quarterly National Accounts Database. 


\section{Table 2}

\section{Prior Distributions for the Two-State Model}

\begin{tabular}{lcc} 
Parameter & Prior Distribution & Hyperparameters \\
\hline $\boldsymbol{\mu}=\left[\mu_{1}, \mu_{2}\right]$ & $N\left(\mathbf{m}_{0}, \sigma^{2} \mathbf{M}_{0}\right)$ & $\mathbf{m}_{0}=[3,-3], \mathbf{M}_{0}=\mathbf{I}_{2}$ \\
$\sigma^{-2}$ & $\Gamma\left(\frac{v_{0}}{2}, \frac{\tau_{0}}{2}\right)$ & $v_{0}=1, \tau_{0}=1$ \\
$\gamma=\left[\alpha_{1}, \alpha_{2}, \beta_{1}, \beta_{2}\right]^{\prime}$ & $N\left(\mathbf{g}_{0}, \mathbf{G}_{0}\right)$ & $\mathbf{g}_{0}=\mathbf{0}_{4}, \mathbf{G}_{0}=2 \mathbf{I}_{4}$ \\
\hline
\end{tabular}

\section{Table 3}

Prior Distributions for the Three-State Model

\begin{tabular}{lcc} 
Parameter & Prior Distribution & Hyperparameters \\
\hline $\boldsymbol{\mu}=\left[\mu_{1}, \mu_{2}, \mu_{3}\right]^{\prime}$ & $N\left(\mathbf{m}_{0}, \sigma^{2} \mathbf{M}_{0}\right)$ & $\mathbf{m}_{0}=[-2,2,6], \mathbf{M}_{0}=\mathbf{I}_{2}$ \\
$\sigma^{-2}$ & $\Gamma\left(\frac{v_{0}}{2}, \frac{\tau_{0}}{2}\right)$ & $v_{0}=1, \tau_{0}=1$ \\
$\gamma_{k}=\left[\alpha_{k 1}, \alpha_{k 2}, \alpha_{k 3}, \beta_{k 1}, \beta_{k 2}, \beta_{k 3}\right]^{\prime}$ & $N\left(\mathbf{g}_{0}, \mathbf{G}_{0}\right)$ & $\mathbf{g}_{0}=\mathbf{0}_{6}, \mathbf{G}_{0}=2 \mathbf{I}_{6}$
\end{tabular}

eters, $\Gamma$; and (iv) the time series of the latent state variable, $\mathbf{s}=\left[s_{1}, \ldots, s_{T}\right]^{\prime}$. We run the sampler for 100,000 iterations, discarding the first 50,000 to achieve convergence.

Tables 2 and 3 show the prior distributions for the parameters of the two- and three-state models, respectively. In each case, we use conjugate prior distributions. Following Kim and Nelson (1999), the steps to draw the average growth rate and error variance parameters are straightforward. The conditional posterior distribution for the vector of average growth rates, $\boldsymbol{\mu}$, is multivariate normal and the posterior for the error variance, $\sigma^{2}$, is inverse gamma.

The transition probability parameters can be rewritten as a difference random utility model (dRUM) as outlined by Frühwirth-Schnatter and Frühwirth (2010) and Kaufmann (2011). Under the dRUM, we assume each state has a continuous, latent utility value. Conditional on knowing the state at each point in time, the observed state is the one with the highest utility. The conditional posterior distribution of the transition parameter vector, $\gamma_{i}$, is multivariate normal for each state $i=1, \ldots, K-1$. The unobserved state variable is drawn using the filter from Hamilton (1989) with the smoothing algorithm from Kim (1994). For the general $K$-state model, we use the multistate extension of the filter as outlined by Kaufmann (2011).

Choosing between using two states (recession and expansion) and three states (recession, low-growth expansion, and high-growth expansion) is a model selection problem. We use the Bayesian information criterion (BIC) to choose which model is best suited for each country. BIC is calculated as

$$
B I C=-2 \log \left[L\left(\Theta, \mathbf{s}, \mathbf{y}, \mathbf{y}^{U S}\right)\right]+N \log (T),
$$

where $N$ is the number of parameters in the model, $T$ is the number of time-series observations, and $L\left(\Theta, \mathbf{s}, \mathbf{y}, \mathbf{y}^{U S}\right)$ is the value of the likelihood function given model parameters $\Theta=\left\{\mu, \sigma^{2}, \alpha, \beta\right\}$, 


\section{Table 4}

Bayesian Information Criterion

\begin{tabular}{lcc} 
Country & Two-state model & Three-state model \\
\hline Canada & 1112.2 & $\mathbf{1 0 5 7 . 6}$ \\
France & 769.1 & $\mathbf{7 4 6 . 3}$ \\
Germany & $\mathbf{1 2 3 8 . 0}$ & 1259.9 \\
Italy & 1195.2 & $\mathbf{1 1 7 4 . 2}$ \\
Japan & $\mathbf{1 0 2 6 . 3}$ & 1048.6 \\
Mexico & $\mathbf{8 0 6 . 8}$ & 855.9 \\
United Kingdom & 1166.1 & $\mathbf{1 1 6 1 . 2}$ \\
NOTE: Bold type indicates the optimal model that minimizes BIC. &
\end{tabular}

the state vector $\mathbf{s}$, and the data $\mathbf{y}=\left[y_{1}, \ldots, y_{T}\right]$ and $\mathbf{y}^{U S}=\left[y_{0}^{U S}, \ldots, y_{T-1}^{U S}\right]$. The BIC accounts for the likelihood of the data while penalizing models with a large number of parameters. Raftery (1995) and Kass and Raftery (1995) show that the BIC approximates the Bayes factor of competing models; thus, it provides an adequate solution to our model selection problem. The BIC is calculated at each iteration of the Gibbs sampler, and the optimal model for each country is the one that minimizes the median BIC calculation.

\section{RESULTS}

Table 4 shows the model selection results for each country. The two-state model is preferred for Germany, Japan, and Mexico, while the three-state model is chosen for Canada, France, Italy, and the United Kingdom. These results suggest a more stable expansion output growth rate for the former countries, while the latter countries appear to have both low- and high-growth expansions.

Table 5 presents the estimated mean growth rate and variance parameters for each country. Germany, Japan, and Mexico each have much higher error variance than the other countries in the sample; it is possible this variance is caused by the lack of the third state in their optimal model to capture high-growth dynamics. The lack of two expansion states also explains the higher estimated mean expansionary growth rate for these countries since the model captures episodes of both high and low growth.

We discuss the remaining results in two subsections. The first outlines the estimated recession timing for each country across time. The second subsection assesses the ability of U.S. output growth to inform business cycle turning points for each country. 
Francis, Owyang, Soques

\section{Table 5}

\section{Estimates for the Average Growth Rate and Variance Parameters}

\begin{tabular}{lccccccc} 
Parameter & Canada & France & Germany & Italy & Japan & $\begin{array}{c}\text { United } \\
\text { Mexico }\end{array}$ & Kingdom \\
\hline$\mu_{1}$ & -2.90 & -3.25 & -2.86 & -2.57 & -3.74 & -4.60 & -2.99 \\
$\mu_{2}$ & 2.66 & 1.49 & 3.19 & 1.69 & 3.21 & 3.66 & 2.82 \\
$\mu_{3}$ & 6.78 & 4.10 & - & 6.60 & - & - & 8.15 \\
$\sigma^{2}$ & 5.19 & 2.44 & 15.53 & 8.97 & 16.22 & 17.21 & 8.46
\end{tabular}

NOTE: The table shows median posterior draws for the state-dependent growth rates, $u_{1}$, and the variance, $\sigma^{2}$.

\section{Timing of Business Cycle Phases}

Figure 2 presents the probability implied by our model that a country is in a state of recession at each period in our sample. In technical terms, these are the posterior probabilities of recession, $\operatorname{Pr}\left[s_{t}=1 \mid \Omega_{T}\right]$, for each country conditional on $\Omega_{T}$, the information at time $t$. For each $t, \operatorname{Pr}\left[s_{t}=1 \mid \Omega_{T}\right]$ is the percentage of Gibbs iterations for which a recession state is drawn at each period. Although all countries in our sample have experienced some similar recessions (e.g., the first oil crisis of the mid-1970s and the Great Recession of 2007-09), there are substantive differences in the timing of countries entering recessions and the durations of recessions. For example, we find that most countries entered recession after the United States had already begun the Great Recession of 2007-09. Although some countries (e.g., Canada, Mexico, and the United Kingdom) exited this recession with the United States, others (e.g., Italy and Japan) experienced lasting effects of the global downturn, leading to a "double-dip" recession.

For completeness, we plot the posterior probability of expansion in Figure 3. Countries following the two-state model (Germany, Japan, and Mexico) have a single expansion state and therefore a single posterior probability of expansion, whereas countries following the three-state model (Canada, France, Italy, and the United Kingdom) have two expansion states (low and high growth). For the latter countries, we include the posterior probabilities of the low-growth expansion state in Figure 3 and separately plot the posterior probabilities for the high-growth state in Figure 4.

Consistent with the empirical literature on business cycles, we find the expansion state(s) are highly persistent with longer average duration(s) than the recession state(s). The highgrowth expansion state accounts for periods of relatively high growth prior to 1985, the beginning of the period known as the Great Moderation. For France, the high-growth expansion state also captures two notable economic periods: the movement away from dirigisme in the late 1980s and the beginning of euro integration in the late 1990s. 


\section{Francis, Owyang, Soques}

Figure 2

\section{Posterior Recession Probabilities}

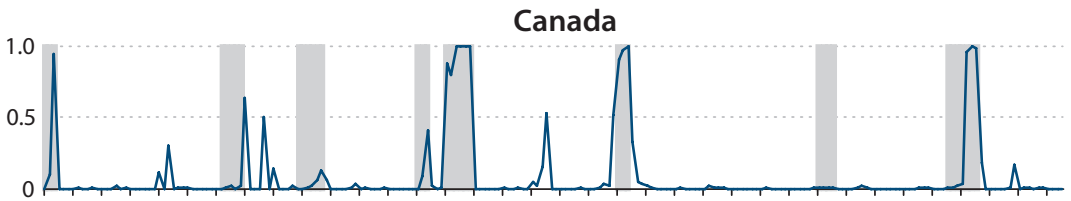

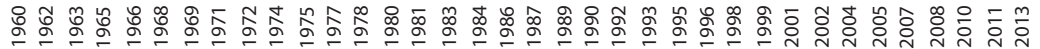
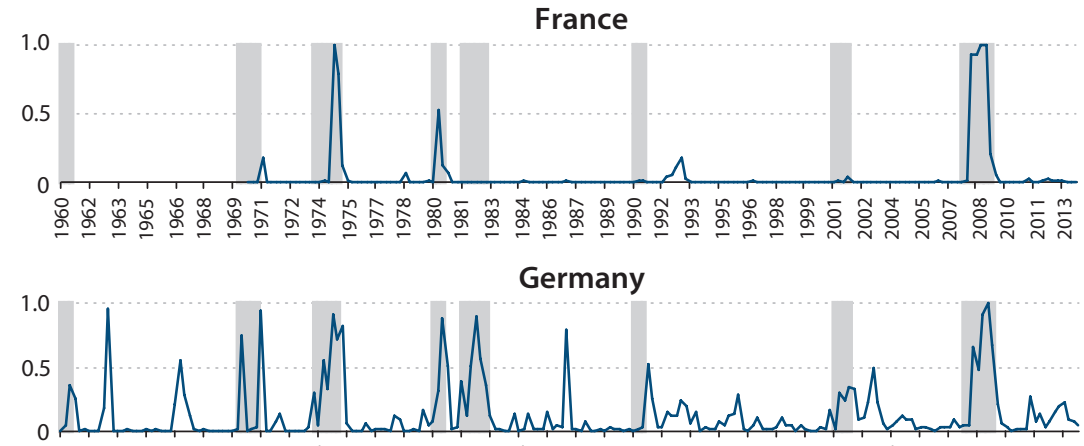

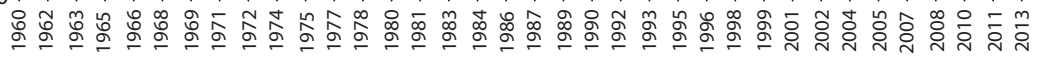

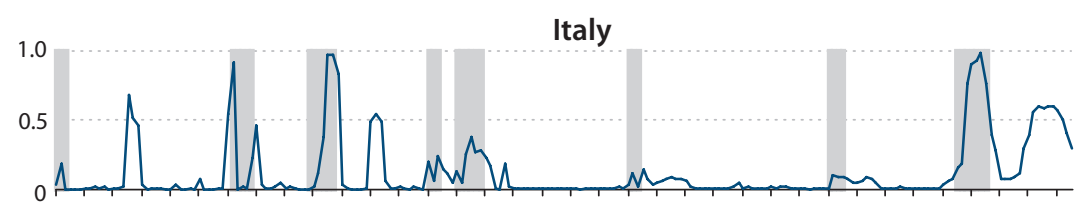

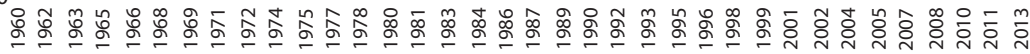

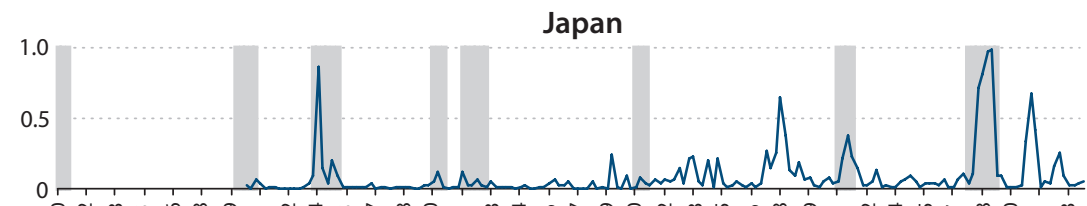

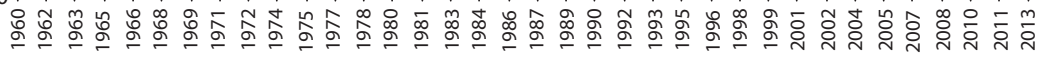
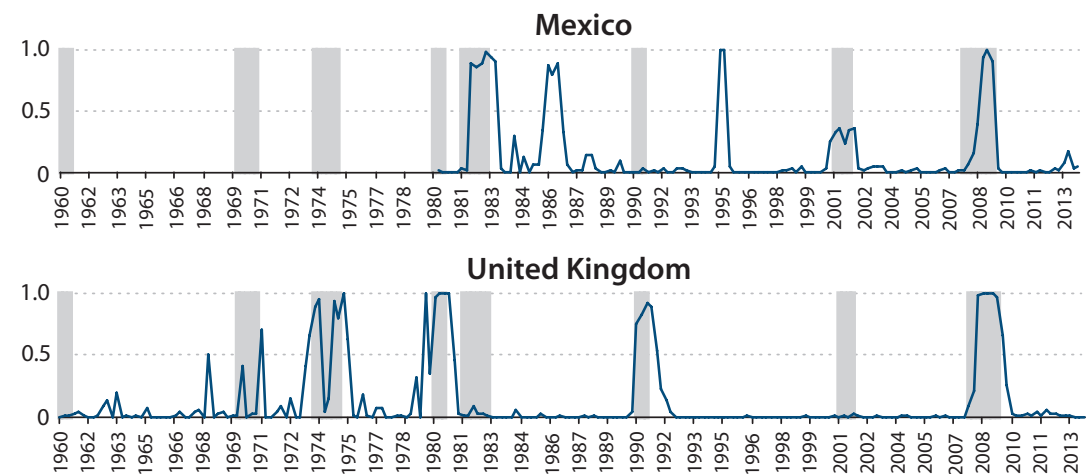

NOTE: The posterior recession probabilities for each country ( $y$-axes) are calculated as the percentage of MCMC draws for which a recession is drawn $\left(s_{t}=1\right)$. The shaded bars indicate U.S. recessions as determined by the National Bureau of Economic Research. 


\section{Figure 3}

\section{Posterior Expansion Probabilities}
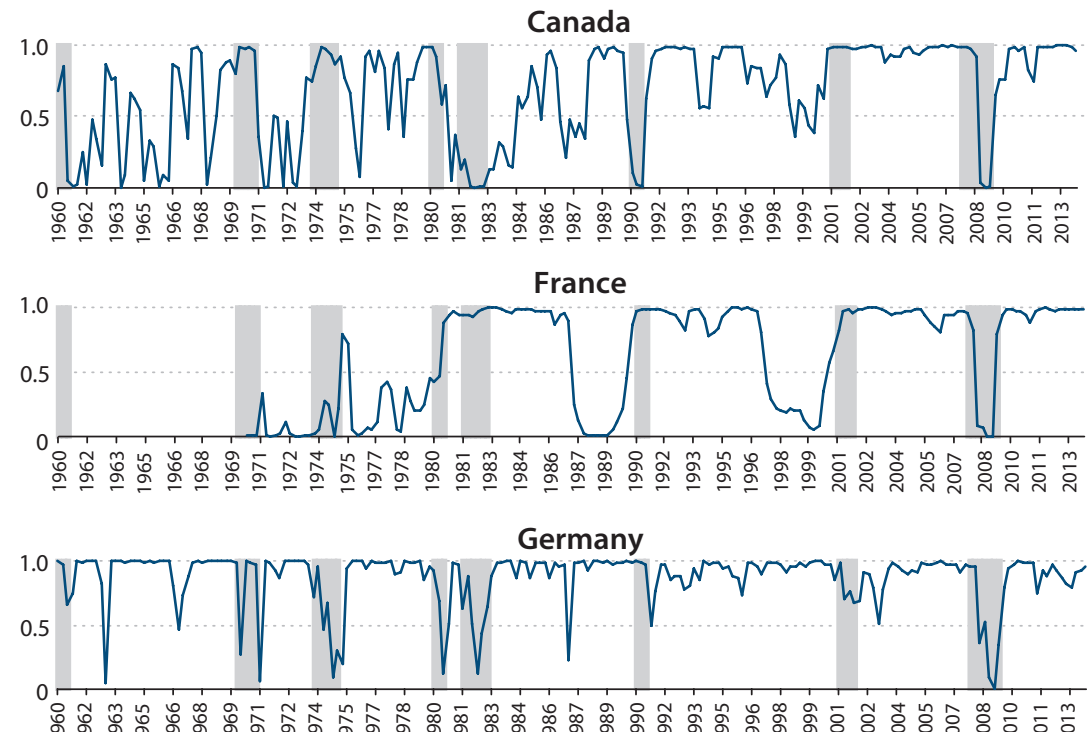

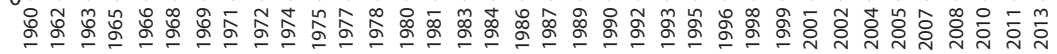

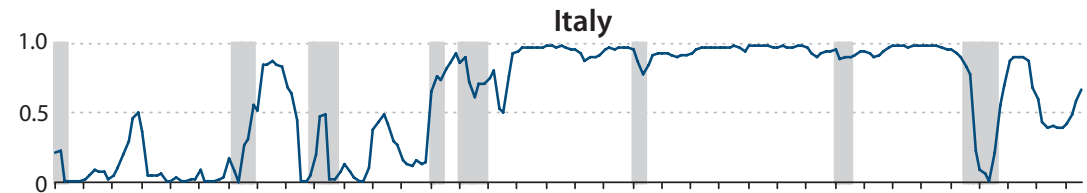

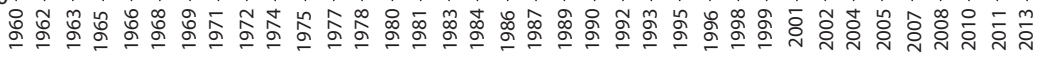

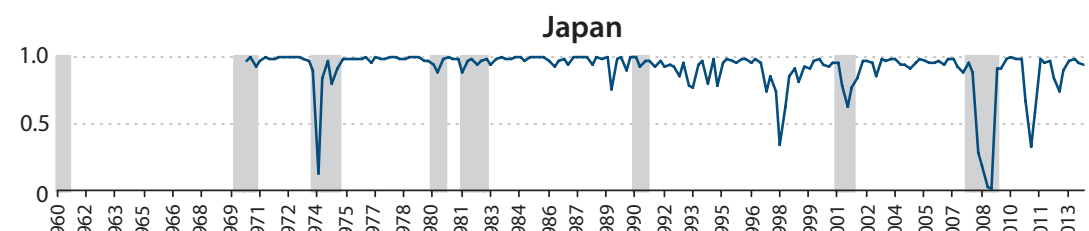

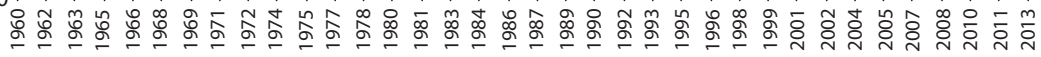

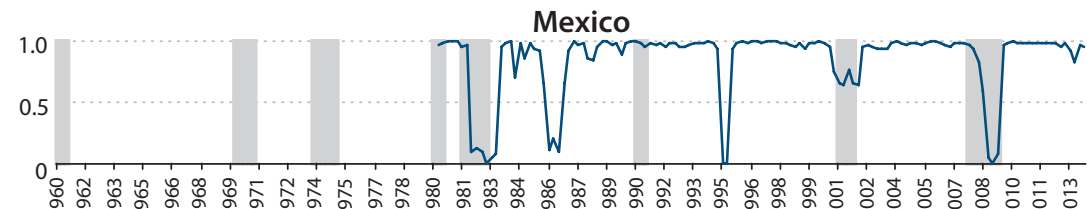

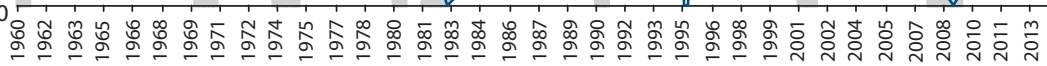

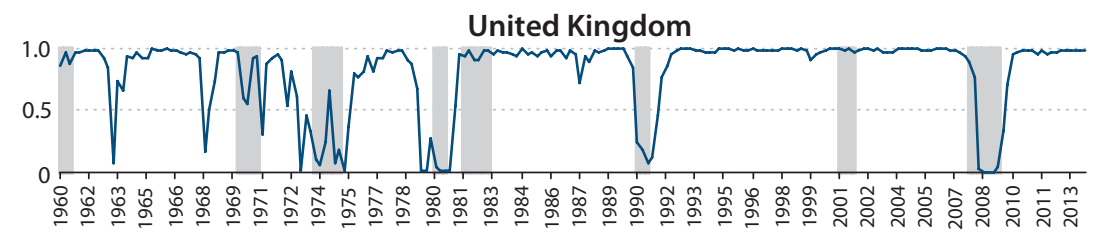

NOTE: The posterior expansion probabilities for each country ( $y$-axes) are calculated as the percentage of MCMC draws for which an expansion is drawn $\left(s_{t}=2\right)$. For countries following the three-state model (Canada, France, Italy, and the United Kingdom), these are the posterior probabilities of the low-growth expansion state. The shaded bars indicate U.S. recessions as determined by the National Bureau of Economic Research. 
Figure 4

Posterior High-Growth Expansion Probabilities
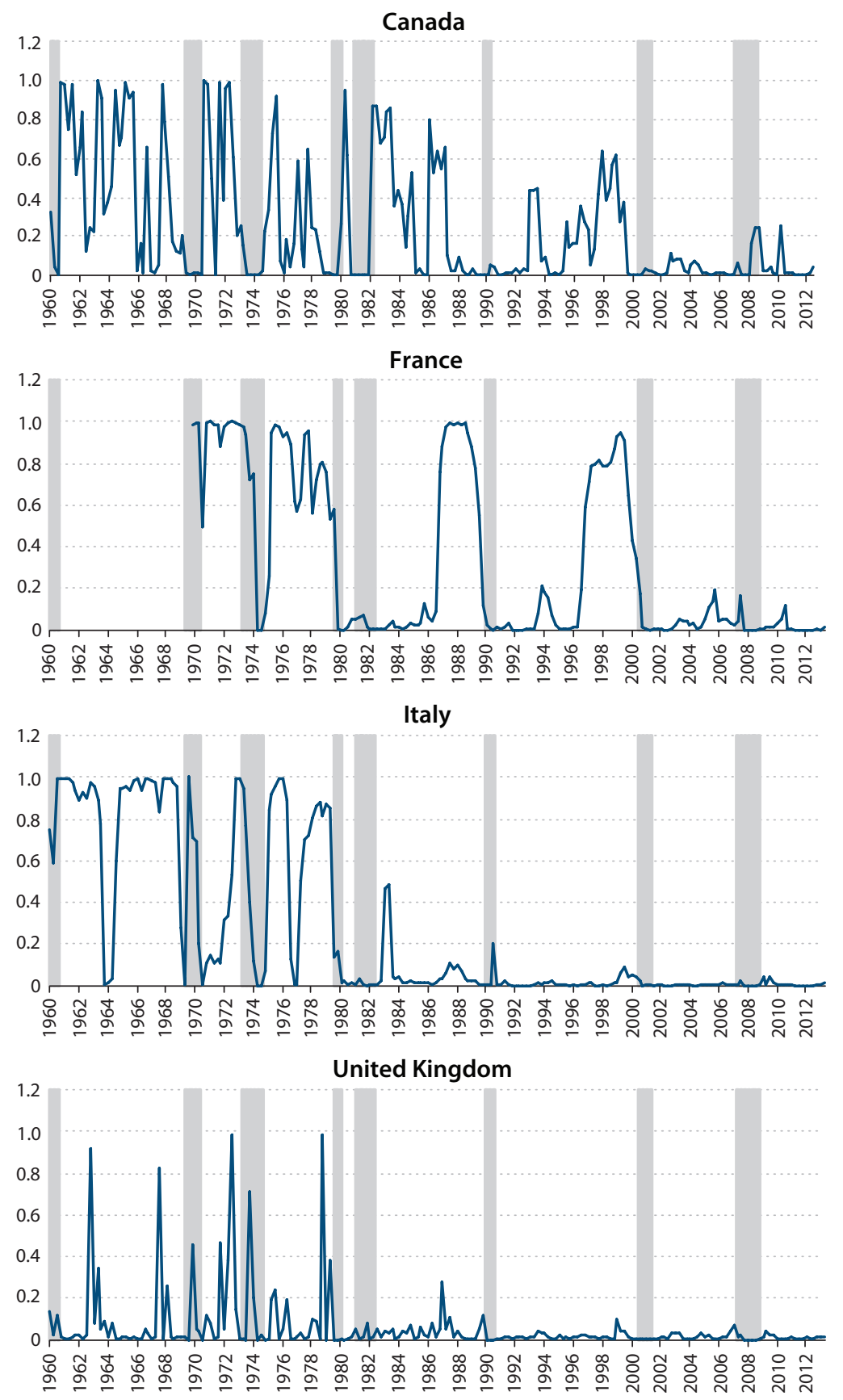

NOTE: The posterior high-growth expansion probabilities ( $y$-axes) for countries following the three-state model (Canada, France, Italy, and the United Kingdom) are calculated as the percentage of MCMC draws for which a high-growth expansion is drawn $\left(s_{t}=3\right)$. The shaded bars indicate U.S. recessions as determined by the National Bureau of Economic Research. 
Francis, Owyang, Soques

\section{Table 6}

\section{Estimates for the Transition Probability Parameters}

\begin{tabular}{|c|c|c|c|c|c|c|c|c|}
\hline & Parameter & Canada & France & Germany & Italy & Japan & Mexico & $\begin{array}{l}\text { United } \\
\text { Kingdom }\end{array}$ \\
\hline \multirow[t]{2}{*}{$p_{11, t}$} & $\alpha_{11}$ & -0.17 & 0.76 & -1.17 & 1.12 & -0.49 & 0.20 & 1.06 \\
\hline & $\beta_{11}$ & -1.35 & -0.81 & -1.12 & -0.52 & -0.25 & -0.91 & -0.81 \\
\hline \multirow[t]{2}{*}{$p_{12, t}$} & $\alpha_{12}$ & -1.10 & -1.46 & -2.73 & -0.59 & -2.91 & -2.78 & -0.84 \\
\hline & $\beta_{12}$ & -2.49 & -1.00 & -1.40 & -1.36 & -0.29 & -0.50 & -1.27 \\
\hline \multirow{2}{*}{$p_{13, t}$} & $\alpha_{13}$ & -2.23 & -3.13 & - & -2.35 & - & - & 0.36 \\
\hline & $\beta_{13}$ & -1.44 & -0.96 & - & -0.35 & - & - & -0.26 \\
\hline \multirow[t]{2}{*}{$p_{21, t}$} & $\alpha_{21}$ & -0.73 & 0.09 & - & -0.18 & - & - & 0.54 \\
\hline & $\beta_{21}$ & -0.46 & -0.87 & - & 0.39 & - & - & 0.82 \\
\hline \multirow[t]{2}{*}{$p_{22, t}$} & $\alpha_{22}$ & 2.51 & 2.94 & - & 3.58 & - & - & 3.16 \\
\hline & $\beta_{22}$ & -1.53 & -0.45 & - & -0.54 & - & - & -0.02 \\
\hline \multirow[t]{2}{*}{$p_{23, t}$} & $\alpha_{23}$ & 0.06 & -2.25 & - & -2.30 & - & - & 0.90 \\
\hline & $\beta_{23}$ & -1.03 & -0.31 & - & -0.65 & - & - & 0.08 \\
\hline
\end{tabular}

NOTE: Median posterior draws for the parameters governing the transition probabilities, $p_{j i, t}=\operatorname{Pr}\left[s_{t}=j \mid s_{t-1}=i, y_{t-1}^{U S}\right] ; \alpha_{j i}$ captures the time-invariant portion of the transition probability; and $\beta_{j i}$ is the coefficient on lagged U.S. output growth. Bold values indicate that 0 lies outside the 68 percent posterior coverage.

\section{Does U.S. Output Growth Drive Business Cycles?}

The focus of this article is determining whether U.S. output growth informs economic turning points of other nations. ${ }^{3}$ In our modeling framework, this relationship is captured in the transition dynamics of the state variable. Table 6 displays the median posterior draws for the transition probability parameters for all countries in our sample. As noted in the section "Determining the Effects of U.S. Output Growth," the coefficients $\beta_{j i}$ in the transition equations suggest how U.S. output growth influences the state dynamics of the country of interest. They are not, however, the sole determinants of the (marginal) effect of a change in lagged U.S. output growth on the transition probabilities on the business cycle of a given country. Because the marginal effects depend on both the value of lagged U.S. output growth $y_{t-1}^{U S}$ and the previous state of the economy $s_{t-1}$, we calculate them across all possible combinations of $s_{t-1}$ and $y_{t-1}^{U S}{ }^{*}$ We do this for each iteration of the Gibbs sampler, thereby constructing the posterior distribution for each of the marginal effects.

Figures 5 through 11 display the marginal effect of a change in lagged U.S. output growth on each of the transition probabilities. The horizontal axis for each figure reflects different values for U.S. output growth, from -4 to +4 standard deviations from its historical average. The vertical axis plots the marginal effect of a change in U.S. output growth on the respective transition probability conditional on the value for $y_{t-1}^{U S}$ and the previous state $s_{t-1}$. In each figure, the blue line represents the posterior median of the marginal effect, and the shaded region represents the 68 percent coverage of the posterior distribution. 


\section{Francis, Owyang, Soques}

\section{Figure 5}

\section{Marginal Effect of a Change in U.S. Output on the Transition Probabilities for Canada}
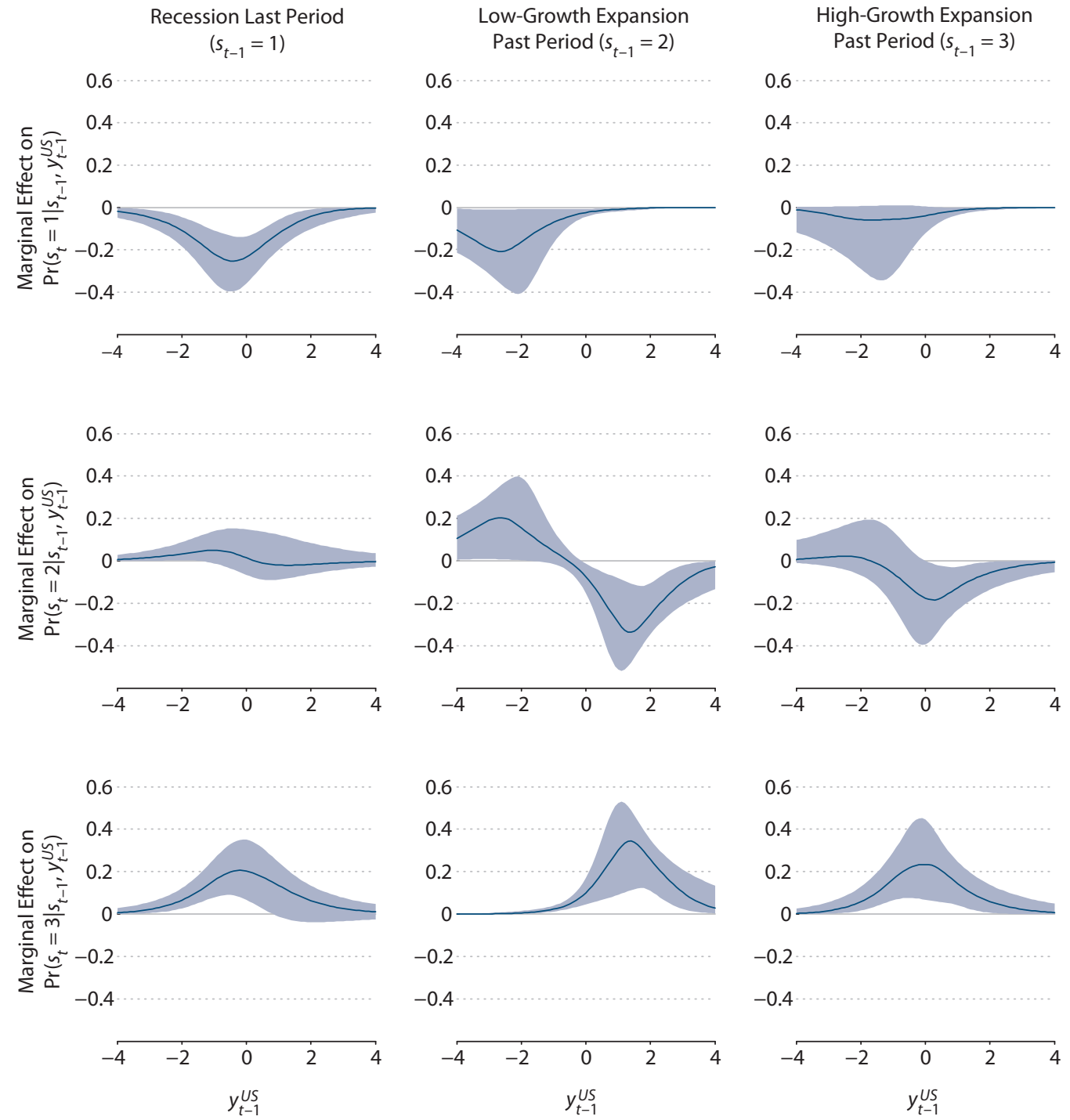

NOTE: The blue line represents the posterior median of the marginal effect of a change in U.S. output growth on the transition probability given the values for lagged U.S. output growth $\left(y_{t-1}^{U S}\right)$ and the past state $\left(s_{t-1}\right)$. The shaded regions reflect the 68 percent coverage of the posterior distribution. 


\section{Figure 6}

\section{Marginal Effect of a Change in U.S. Output on the Transition Probabilities for France}

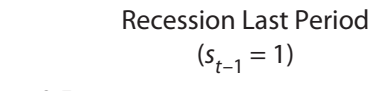

0.5
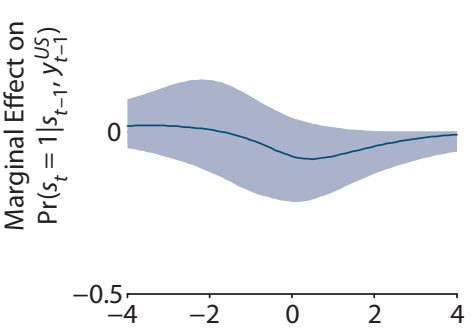

0.5
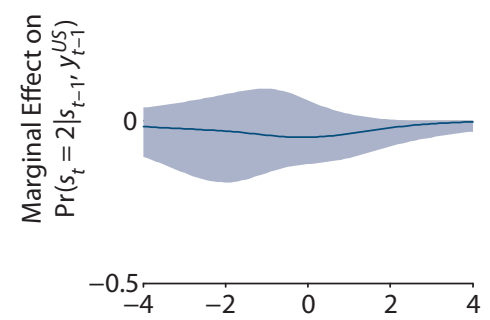

0.5
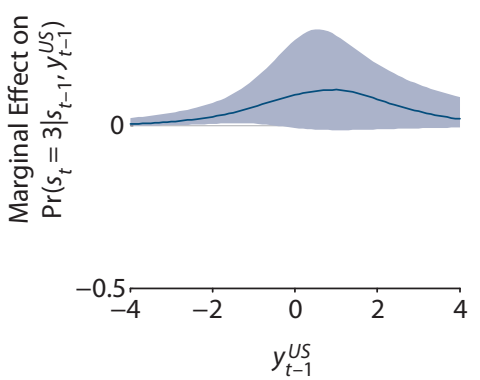

Low-Growth Expansion

Past Period $\left(s_{t-1}=2\right)$

0.5
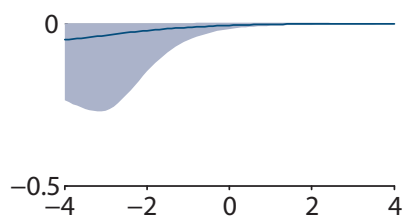

0.5
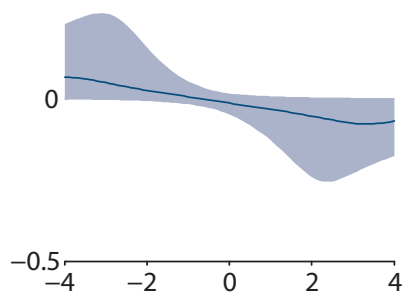

0.5
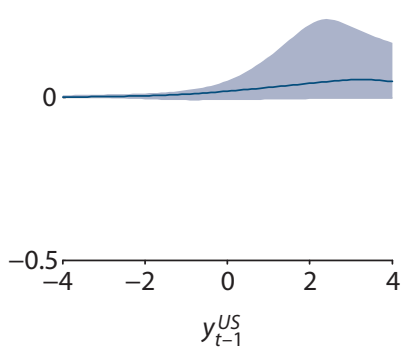

High-Growth Expansion

Past Period $\left(s_{t-1}=3\right)$

0.5
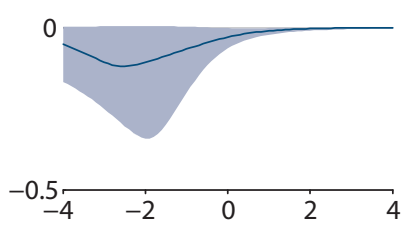

0.5
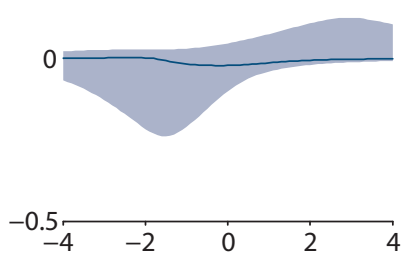

0.5

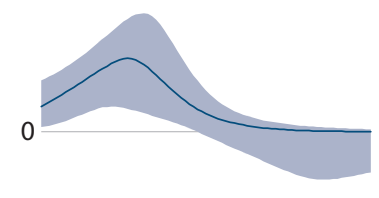

$\begin{array}{llcll}-0.5 & -2 & 0 & 2 & 4 \\ & & \begin{array}{c}1 \\ y_{t-1}^{U S}\end{array} & & \end{array}$

NOTE: The blue line represents the posterior median of the marginal effect of a change in U.S. output growth on the transition probability given the values for lagged U.S. output growth $\left(y_{t-1}^{U S}\right)$ and the past state $\left(s_{t-1}\right)$. The shaded regions reflect the 68 percent coverage of the posterior distribution. 


\section{Francis, Owyang, Soques}

\section{Figure 7}

Marginal Effect of a Change in U.S. Output on the Transition Probabilities for Germany

Recession Last Period

$$
\left(s_{t-1}=1\right)
$$

0.5

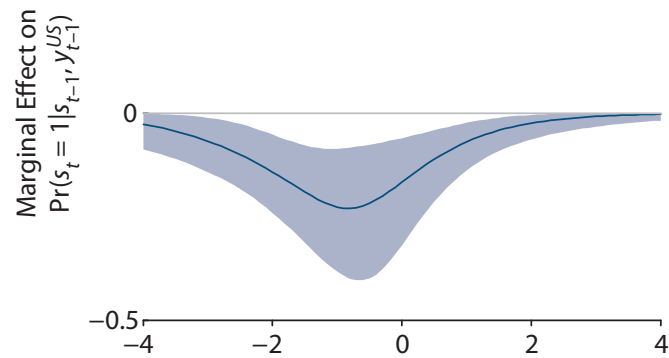

0.5

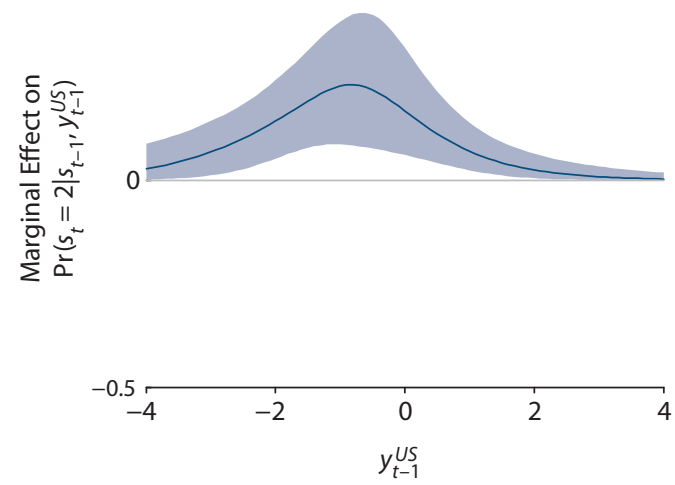

Recession Last Period

$$
\left(s_{t-1}=2\right)
$$

0.5

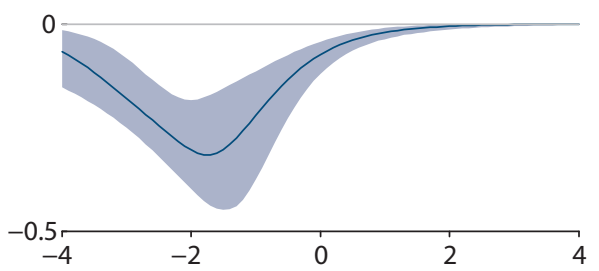

0.5
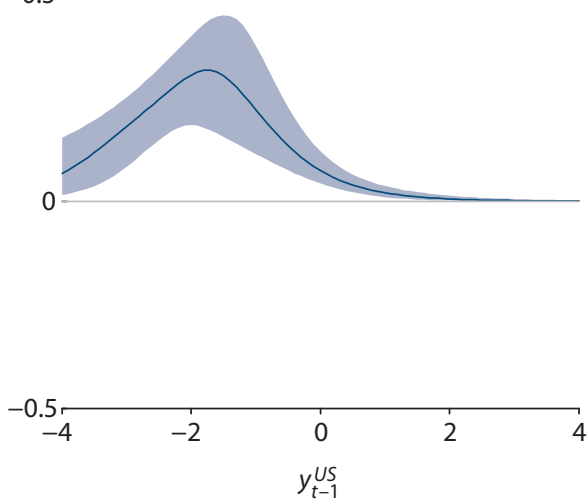

NOTE: The blue line represents the posterior median of the marginal effect of a change in U.S. output growth on the transition probability given the values for lagged U.S. output growth $\left(y_{t-1}^{U S}\right)$ and the past state $\left(s_{t-1}\right)$. The shaded regions reflect the 68 percent coverage of the posterior distribution. 


\section{Figure 8}

\section{Marginal Effect of a Change in U.S. Output on the Transition Probabilities for Italy}

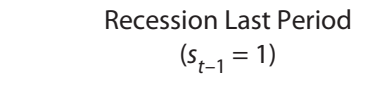

0.5

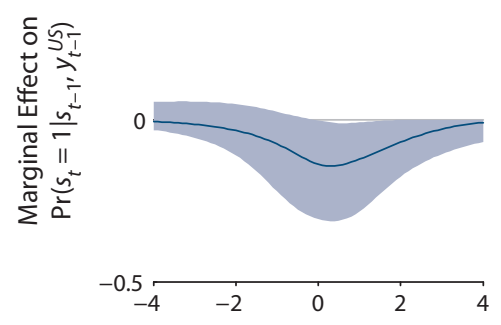

0.5

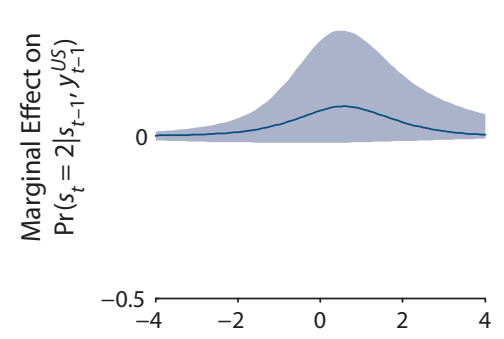

0.5

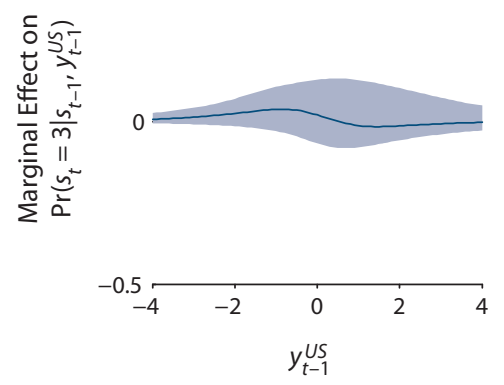

Low-Growth Expansion
Past Period $\left(s_{t-1}=2\right)$

0.5

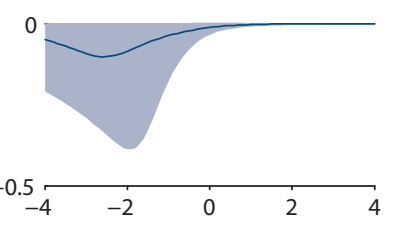

0.5
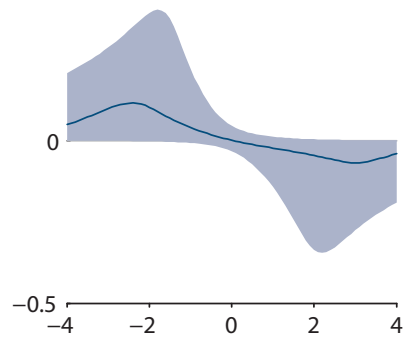

0.5
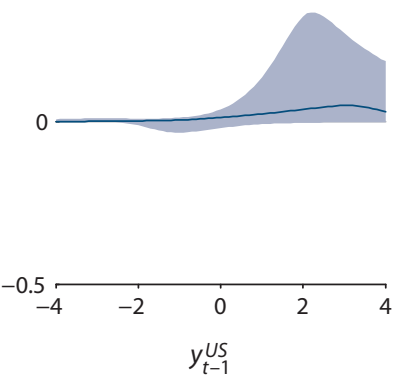

High-Growth Expansion

Past Period $\left(s_{t-1}=3\right)$

0.5

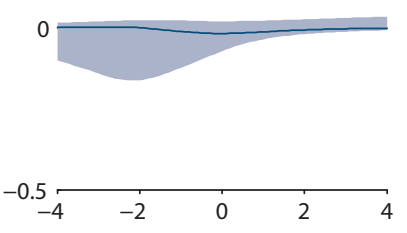

0.5
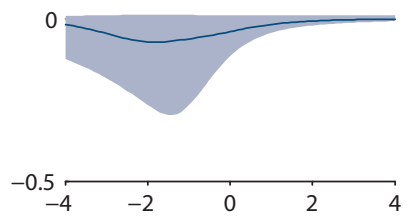

0.5
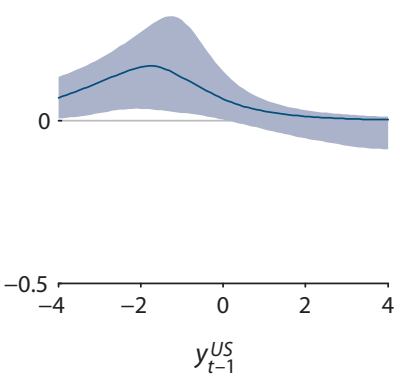

NOTE: The blue line represents the posterior median of the marginal effect of a change in U.S. output growth on the transition probability given the values for lagged U.S. output growth $\left(y_{t-1}^{U S}\right)$ and the past state $\left(s_{t-1}\right)$. The shaded regions reflect the 68 percent coverage of the posterior distribution. 


\section{Francis, Owyang, Soques}

\section{Figure 9}

\section{Marginal Effect of a Change in U.S. Output on the Transition Probabilities for Japan}

Recession Last Period

$$
\left(s_{t-1}=1\right)
$$

0.5

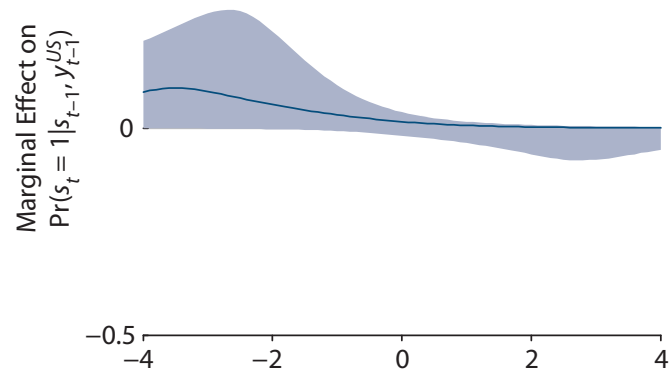

0.5

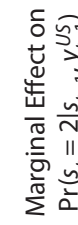

을

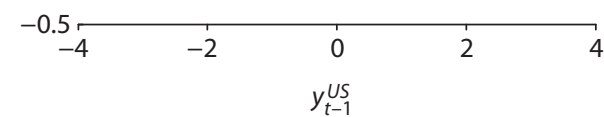

Recession Last Period

$$
\left(s_{t-1}=2\right)
$$

0.5
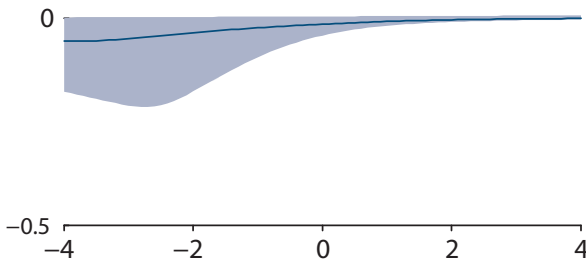

0.5
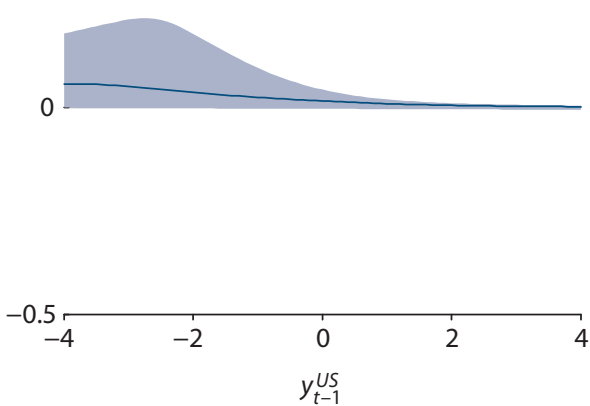

NOTE: The blue line represents the posterior median of the marginal effect of a change in U.S. output growth on the transition probability given the values for lagged U.S. output growth $\left(y_{t-1}^{U S}\right)$ and the past state $\left(s_{t-1}\right)$. The shaded regions reflect the 68 percent coverage of the posterior distribution. 


\section{Figure 10}

Marginal Effect of a Change in U.S. Output on the Transition Probabilities for Mexico

Recession Last Period

$$
\left(s_{t-1}=1\right)
$$

0.5

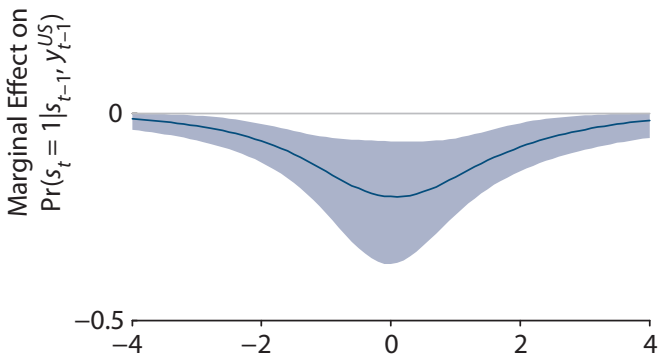

0.5

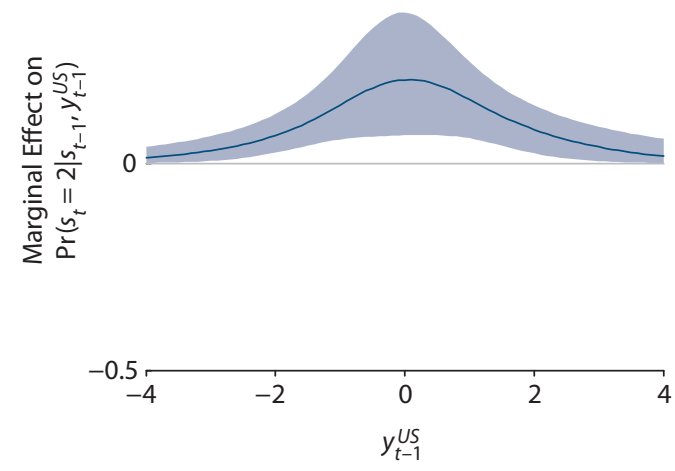

Recession Last Period

$\left(s_{t-1}=2\right)$

0.5
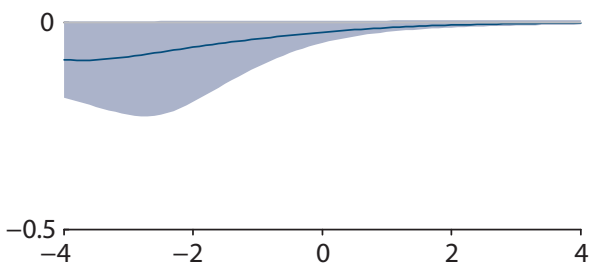

0.5
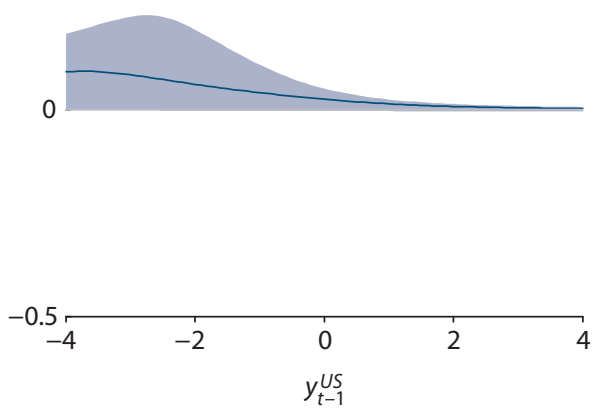

NOTE: The blue line represents the posterior median of the marginal effect of a change in U.S. output growth on the transition probability given the values for lagged U.S. output growth $\left(y_{t-1}^{U S}\right)$ and the past state $\left(s_{t-1}\right)$. The shaded regions reflect the 68 percent coverage of the posterior distribution. 


\section{Francis, Owyang, Soques}

\section{Figure 11}

\section{Marginal Effect of a Change in U.S. Output on the Transition Probabilities for the United Kingdom}
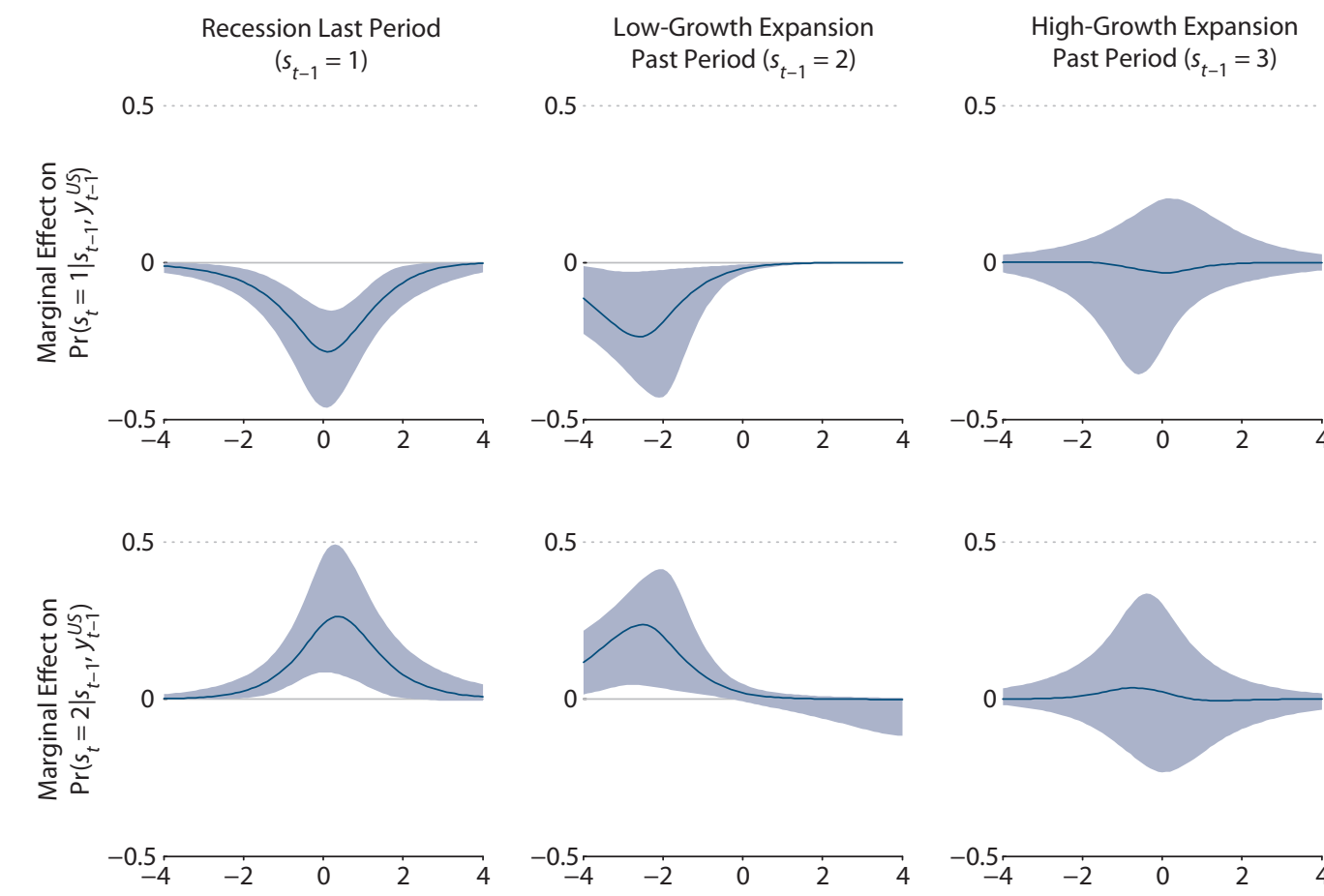

0.5
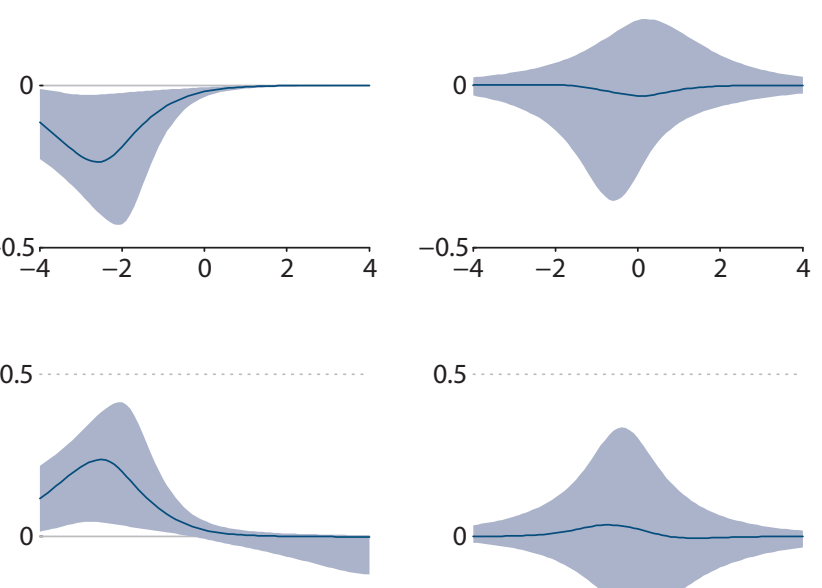

0.5

0.5

0.5
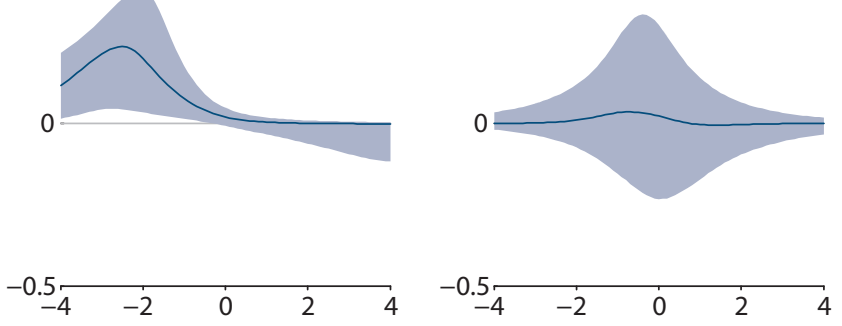

0.5
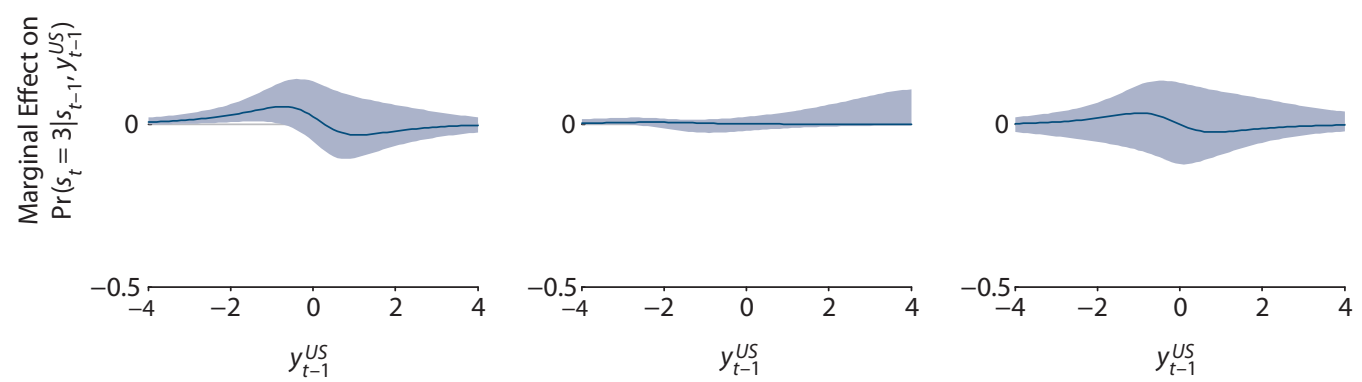

NOTE: The blue line represents the posterior median of the marginal effect of a change in U.S. output growth on the transition probability given the values for lagged U.S. output growth $\left(y_{t-1}^{U S}\right)$ and the past state $\left(s_{t-1}\right)$. The shaded regions reflect the 68 percent coverage of the posterior distribution. 
A positive marginal effect implies that an increase in lagged U.S. output growth increases the respective transition probability $p_{j i, t}=\operatorname{Pr}\left(s_{t}=j \mid s_{t-1}=i, y_{t-1}^{U S}\right)$. Conversely, a negative marginal effect implies that an increase in lagged U.S. output growth decreases the respective transition probability. That is, for countries whose economies move with the U.S. economy, we expect to find a positive (negative) marginal effect of $y_{t-1}^{U S}$ on the probability of transitioning to an expansion (recession) and the duration of expansion (recession). For countries whose economies move opposite to the U.S. economy, we expect to find a negative (positive) marginal effect of $y_{t-1}^{U S}$ on the probability of transitioning to an expansion (recession) and the duration of expansion (recession).

For each country, we assess the ability of U.S. output growth to inform (i) the timing of entering a recession, (ii) the duration of a recession, and (iii) transitions between states of lowand high-growth expansion (for countries following the three-state model). We assess the first dynamic by examining the marginal effect of U.S. output growth on the transition probability from expansion $\left(s_{t-1}=2\right.$ or 3$)$ to recession $\left(s_{t-1}=1\right)$, so the relevant transition probabilities are $p_{12, t}$ and $p_{13, t}$. For recession duration, we determine whether U.S. output influences the transition probability of staying in recession this period $\left(s_{t-1}=1\right)$ given that the economy was in recession during the previous period $\left(s_{t-1}=1\right)$ with relevant transition probability $p_{11, t}$. We analyze the last aspect by examining both the persistence probability of both low-expansion $\left(p_{22, t}\right)$ and high-expansion $\left(p_{33, t}\right)$ states in addition to the transition probabilities between the two expansion states $\left(p_{23, t}\right)$ and $\left(p_{32, t}\right)$.

The three countries most influenced by U.S. output growth are Canada, Germany, and the United Kingdom. For these countries, lagged U.S. output growth influences both the timing of entering a recession and the duration of a recession. The results show that the economies of each of these countries move with the U.S. economy: Higher U.S. output growth implies a lower probability of recession, and lower output growth implies a higher probability of recession $\left(\uparrow y_{t-1}^{U S} \Rightarrow \downarrow p_{1 i, t}, \uparrow p_{2 i, t}\right.$ for all $\left.i\right)$. Figure 7 presents the marginal effects for Germany, which follows the simpler two-state model. For Germany, the marginal effect of U.S. output growth is largest (in absolute terms) at low levels of $y_{t-1}^{U S}$, or when the United States is likely in a state of recession. Therefore, when the U.S. economy is in dire circumstances (as signaled by low output growth), Germany is more susceptible to any further movements in U.S. output relative to more "normal" economic times.

In addition to informing the timing and duration of recessions, U.S. output growth also influences the transition dynamics of low- and high-growth expansion for Canada (see Figure 5). When U.S. growth is relatively low (i.e., below its historical mean), increases in U.S. output growth imply a higher persistence of low-growth expansion $\left(\uparrow p_{22, t}\right)$. However, when U.S. growth is relatively high (i.e., above its historical mean), increases in U.S. output growth (i) decrease the duration of low-growth expansion and (ii) increase both the probability of transitioning to high-growth expansion $\left(\uparrow_{32, t}\right)$ and the persistence probability of high-growth expansion $\left(\uparrow_{p_{33, t}}\right)$. This result reflects the strong economic relationship between Canada and the United States since it informs not only the timing of recessions but also the timing of varying degrees of expansion. 


\section{Francis, Owyang, Soques}

For Mexico, lagged U.S. output growth informs the duration of a recession but not the timing of entering a recession. When U.S. output growth falls, the persistence probability of recession in Mexico rises $\left(\uparrow_{11, t}\right)$, implying a longer expected duration of recession. The lack of influence of U.S. output growth on the timing of Mexico entering a recession could be due to the fact that Mexico experienced idiosyncratic recessions unrelated to the United States (e.g., the 1994 Mexican peso crisis), which tended to be shorter than coincident recessions with the United States (e.g., the recession of the early 1980s and the Great Recession of 2007-09).

The results for France, Italy, and Japan suggest that lagged U.S. output growth does not influence the timing or duration of recessions for these countries. For France and Italy, increases in U.S. output growth increase the persistence probability of high-growth expansion $\left(\uparrow^{\uparrow} p_{33, t}\right)$ but only at low levels of U.S. output growth.

Recent studies on business cycle synchronization offer two possible explanations for our results: stage of development and common language. Regarding the first explanation, Kose, Otrok, and Prasad (2012) find that emerging market economies and advanced economies have decoupled during the globalization period, but the economies of countries within each respective group have converged. This finding is consistent with our result that the United States is more informative for the business cycles of advanced countries such as Canada, Germany, and the United Kingdom and less so for the developing country in our sample, Mexico.

Another plausible explanation is that countries with a common language tend to have similar business cycles. ${ }^{5}$ We find that U.S. output growth informs the business cycles for each of the countries in our sample whose de facto or official language is English.

\section{CONCLUSION}

In this article, we assessed whether the U.S. economy drives business cycle turning points of other nations. We extended the nonlinear business cycle model of Hamilton (1989) to allow U.S. output growth to influence the probability of a country moving between states of expansion and recession. We found that the United States does inform the timing and duration of recessions for Canada, Germany, the United Kingdom, and, to a lesser extent, Mexico. Additionally, we found no informative relationship between U.S. output growth and the business cycles of France, Italy, and Japan.

It is important to keep in mind that our results suggest only that the U.S. economy does not appear to lead the economies of France, Italy, and Japan. If the business cycles in these countries react intraquarterly to fluctuations in U.S. output, the leading relationship of the United States would show up as a false negative in the estimation. Further, if a common world shock affects the United States before other countries, the result might be a false positive. However, our analysis provides a framework for approaching the question of Granger causality across business cycles. 


\section{NOTES}

1 For analysis of the specific mechanisms (trade openness, financial market linkages, and so on) by which the United States transmits shocks to the rest of the world, see Calvo, Leiderman, and Reinhart (1993); Kose and Yi (2001); Uribe and Yue (2006); Maćkowiak (2007); Edwards (2010); Bayoumi and Bui (2010); and Kazi, Wagan, and Akbar (2013).

2 In this case, we assume that the foreign output growth rate is exogenous and unaffected by the domestic regime.

3 Note that we cannot infer causality of the business cycle in the structural sense, but rather we assess if U.S. output acts as an informative indicator of other countries' turning points. Therefore, for the countries for which our model indicates that U.S. output growth is not a significant indicator, this assessment does not imply a lack of structural mechanisms that propagate shocks between the two nations.

4 We consider values for $y_{t-1}^{u s}$ between -4 standard deviations and +4 standard deviations from its historical mean. This corresponds to a range of -10.5 to 16.6 , which includes the historical minimum (-8.7) and maximum (15.3) values of U.S. output growth.

5 See Artis, Chouliarakis, and Harischandra (2011); Francis, Owyang, and Savascin (2012); and Ductor and LeivaLeon (2014).

\section{REFERENCES}

Antonakakis, Nikolaos. "Business Cycle Synchronization During US Recessions Since the Beginning of the 1870s." Economics Letters, November 2012, 117(2), pp. 467-72.

Arora, Vivek and Vamvakidis, Athanasios. "The Impact of U.S. Economic Growth on the Rest of the World: How Much Does It Matter?" Journal of Economic Integration, March 2004, 19(1), pp. 1-18.

Artis, Michael J.; Chouliarakis, George and Harischandra, P.K.G. “Business Cycle Synchronization Since 1880." Manchester School, March 2011, 79(2), pp. 173-207.

Bayoumi, Tamim and Bui, Trung. "Deconstructing the International Business Cycle: Why Does a U.S. Sneeze Give the Rest of the World a Cold?" IMF Working Paper No. 10/239, International Monetary Fund, October 2010; https://www.imf.org/external/pubs/ft/wp/2010/wp10239.pdf.

Billio, Monica; Casarin, Roberto; Ravazzolo, Francesco and van Dijk, Herman K. "Interactions Between Eurozone and US Booms and Busts: A Bayesian Panel Markov-Switching VAR Model." Working Paper No. 2013/20, Norges Bank, August 20, 2013; http://static.norges-bank.no/pages/97748/Norges_Bank_Working_Paper_2013_20.pdf.

Burns, Arthur F. and Mitchell, Wesley C. Measuring Business Cycles. New York: National Bureau of Economic Research, 1946.

Calvo, Guillermo A.; Leiderman, Leonardo and Reinhart, Carmen M. “Capital Inflows and Real Exchange Rate Appreciation in Latin America: The Role of External Flows." IMF Staff Papers, March 1993, 40(1), pp. 108-51.

Diebold, Francis X.; Lee, Joon-Haeng and Weinbach, Gretchen C. "Regime Switching with Time-Varying Transition Probabilities," in Colin P. Hargreaves, ed., Nonstationary Time Series Analysis and Cointegration (Advanced Texts in Econometrics series). Chap. 10. Oxford: Oxford University Press, 1994.

Ductor, Lorenzo and Leiva-Leon, Danilo. "Global Business Cycles Interdependence: Dynamics and Determinants." Working paper, August 2014; https://sites.google.com/site/daniloleivaleon/files/Ductor_Leiva-Leon_2014_.pdf.

Edwards, Sebastian. "The International Transmission of Interest Rate Shocks: The Federal Reserve and Emerging Markets in Latin America and Asia." Journal of International Money and Finance, June 2010, 29(4), pp. 685-703.

Filardo, Andrew J. "Business-Cycle Phases and Their Transitional Dynamics." Journal of Business and Economic Statistics, July 1994, 12(3), pp. 299-308.

Francis, Neville; Owyang, Michael T. and Savascin, Özge. "An Endogenously Clustered Factor Approach to International Business Cycles." Federal Reserve Bank of St. Louis Working Paper No. 2012-014A, April 2012; http://research.stlouisfed.org/wp/2012/2012-014.pdf. 


\section{Francis, Owyang, Soques}

Frühwirth-Schnatter, Sylvia and Frühwirth, Rudolf. "Data Augmentation and MCMC for Binary and Multinomial Logit Models," in Kneib, Thomas and Tutz, Gerhard, eds., Statistical Modelling and Regression Structures: Festschrift in Honour of Ludwig Fahrmeir. Heidelberg: Springer-Verlag, 2010, pp. 111-32.

Goldfeld, Stephen M. and Quandt, Richard E. "A Markov Model for Switching Regressions." Journal of Econometrics, March 1973, 1(1), pp. 3-15.

Hamilton, James D. "A New Approach to the Economic Analysis of Nonstationary Time Series and the Business Cycle." Econometrica, March 1989, 57(2), pp. 357-84.

Helbling, Thomas; Berezin, Peter; Kose, Ayhan; Kumhof, Michael; Laxton, Doug and Spatafora, Nikola. "Decoupling the Train? Spillovers and Cycles in the Global Economy." World Economic Outlook, April 2007, pp. 121-60; http://www.imf.org/external/pubs/ft/weo/2007/01/pdf/c4.pdf.

Kass, Robert E. and Raftery, Adrian E. "Bayes Factors." Journal of the American Statistical Association, June 1995, 90(430), pp. 773-95.

Kaufmann, Sylvia. "K-State Switching Models with Endogenous Transition Distributions." SNB Working Paper No. 2011-13, Swiss National Bank, November 2011; http://www.snb.ch/n/mmr/reference/working_paper_2011_13/source/working_paper_2011_13.n.pdf.

Kazi, Irfan Akbar; Wagan, Hakimzadi and Akbar, Farhan. "The Changing International Transmission of US Monetary Policy Shocks: Is There Evidence of Contagion Effect on OECD Countries." Economic Modeling, January 2013, 30, pp. 90-116.

Kim, Chang-Jin. "Dynamic Linear Models with Markov-Switching." Journal of Econometrics, January-February 1994, 60(1-2), pp. 1-22.

Kim, Chang-Jin and Murray, Chris J. "Permanent and Transitory Components of Recessions." Empirical Economics, 2002, 27(2), pp. 163-83.

Kim, Chang-Jin and Nelson, Charles R. State-Space Models with Regime Switching. Cambridge, MA: MIT Press, 1999.

Kim, Chang-Jin and Piger, Jeremy. "Common Stochastic Trends, Common Cycles, and Asymmetry in Economic Fluctuations." Journal of Monetary Economics, September 2002, 49(6), pp. 1189-211.

Kose, M. Ayhan; Otrok, Christopher and Prasad, Eswar. "Global Business Cycles: Convergence or Decoupling?" International Economic Review, May 2012, 53(2), pp. 511-38.

Kose, M. Ayhan and Yi, Kei-Mi. "International Trade and Business Cycles: Is Vertical Specialization the Missing Link?" American Economic Review, May 2001, 91(2), pp. 371-75.

Maćkowiak, Bartosz. “External Shocks, U.S. Monetary Policy and Macroeconomic Fluctuations in Emerging Markets." Journal of Monetary Economics, November 2007, 54(8), pp. 2512-20.

Raftery, Adrian E. "Bayesian Model Selection in Social Research." Sociological Methodology, 1995, 25, pp. 111-63.

Uribe, Martin and Yue, Vivian Z. "Country Spreads and Emerging Countries: Who Drives Whom?" Journal of International Economics, June 2006, 69(1), pp. 6-36.

World Bank. World Development Indicators 2012. Washington, DC: World Bank, 2012; http://data.worldbank.org/data-catalog/world-development-indicators/wdi-2012. 